\title{
Employee attitude and customer satisfaction in selected hotels in Kampala,
} Uganda

\author{
Ahmed Jowalie Wampande \\ Lecturer, Tourism \& Hospitality Management, Faculty of Management Sciences, Busitema University, Uganda \\ jwampande@fms.busitema.ac.ug,wampandej@gmail.com

\section{Olutayo K. Osunsan} \\ Lecturer, Business Management, College of Economics and Management (CEM), Kampala International University, \\ Uganda \\ oosunsan@kiu.ac.ug
}

Received: 21/11/2020 Revised: 5/12/2020 Accepted: 14/12/2020 DOI: https://doi.org/10.31559/IJHTS2020.1.2.8

\begin{abstract}
:
This study adopted a cross sectional survey design to investigate the effect of employee attitude on customer satisfaction in selected hotels in Kampala, Uganda. Using simple random sampling, 179 hotel employees were considered in the study. The findings revealed that employee attitude was generally poor ( (mean $=1.09)$, while customer satisfaction was at moderate $($ mean $=1.89)$ levels. The study also revealed a significant positive relationship between employee attitude and customer satisfaction among the selected hotel employees $\left(R^{2}=0.558, P<0.05\right)$. The conclusion drawn was that employee attitude was a suitable predictor of customer satisfaction in the selected hotels. The recommendation was given that then owners and hotel management have to focus on facilitating employee development, engagement and empowerment to enable them develop a more positive attitude towards their job.
\end{abstract}

Keywords: Employee Attitude; Customer Satisfaction; Hotels; Kampala; Uganda.

\section{Introduction}

In a competitive market economy, employees' attitude is a fundamental locus point for determining and attaining efficiency, effectiveness and customer satisfaction in an Organization (Kwizera, et al 2019), especially in a service sector and hospitality industry in particular. Attitude is crucial to customer satisfaction in the service and hospitality industry world over among employees (Oni, Adewoye, \& Eweoya, 2016). The services provided in the hospitality industry are intangible and inseparable from the service provider. Due to these attributes the assessment of service quality is principally subjective and resides mainly with the customer and their perception of the experience (Maggon \& Chaudhry, 2018). Subsequently human resource procedures, practices and policies with regards to employee incentives among others are vital for the formation of an environment that endorses customer oriented behavior (Namuleme, et al 2020).

Furthermore, the dynamic business environment with relations to the covid19 pandemic and rising customer power have inspired businesses to embrace a customer-focused strategy (Shin \& Kang, 2020). Consequently, exceptional business processes and intangible assets such as brands, powerful human resources and customer satisfaction, might become the most indispensable sources of sustainable competitive advantages (Kasemsap, 2017). Customer satisfaction is an imperative to investigate for several reasons: (i) customer satisfaction is a rational gauge for non-financial performance for hotels and can thus ensure their survival. (ii) customer satisfaction is not part of a firm's financial reporting and not a financial indicator that can negatively be influenced by heavy investments in innovation (Mahmoud, Hinson \& Anim, 2018). (iii) satisfaction gauges signify an indicator of the hotels' standing in the competition for customers. (iv)a hotel's customer satisfaction rating signifies the repute and brand of the hotel compared to others. These rating are used by travellers and customers as a whole before making a booking (Kasemsap, 2017; Obiero, 2018). 
Before the outbreak of the Covid19 pandemic, the hotel industry had experienced significant growth in Uganda and world over. The increased number of restaurant choices for consumers has fostered heightened competition among dining establishments and hotels (Nakazibwe, 2018). Coupled with the fact that there is a high turnover among hotel employees in Kampala (Nambooze, 2019), suggesting there might be an issue with employees and the working conditions. This has called for the need to guarantee customer satisfaction among hotels in order to retain their clientele, however this practically impossible without a positive employee attitude to their work (Lee, Moon \& Song, 2018). The purpose of this study therefore is to examine the relationship between employee attitude and customers satisfaction in selected hotels in Kampala, Uganda. This paper sought to build on prior studies (Kurdi, et al 2020) by investigative the degree to which employee attitude affected customer satisfaction.

\section{Literature Review}

\subsection{Employee Attitude}

Employees play a significant role in organisation success and competitiveness and this feeds into the confusion and debate among practitioners on the topic of employee attitudes. Employee attitude varies from employee to employee with respect to their jobs, their careers, and their organizations (Lee, Moon \& Song, 2018). The need by businesses to retain and attract the right talents and foster the right attitude has led to the measuring of employees' attitude provides a signal on how effective the organization is in promoting a favourable environment which breeds the right attitude among employees towards their Job and employer (Balta, 2018).

A positive attitude is achieved through many ways such as good pay (Ogbonnaya, Daniels \& Nielsen, 2017), training and development that facilitates employees with the necessary skills and knowledge to fulfil the businesses objectives (Fletcher, Alfes \& Robinson, 2018). Wikhamn (2019) emphasized the role of innovative and sustainable human resource management that develops employee competence in numerous ways as a means of imparting commitment, the result of which can be seen in the employees improved performance. Organizational support has been documented to influence employee performance in several ways (Kwizera, et al 2019). Effective compensation strategies have also been pointed out as a practice that creates increased commitment through compensating the employees in line with their superior performance, using both financial and non-financial means (Ogbonnaya, Daniels \& Nielsen, 2017). Similarly, communication gives all employees a voice within the organization, which enables each employee to understand what is expected in regards to their responsibilities and organizational mission statement. Good or positive employee attitude will enable employees offer good service with a feeling of belongingness (King et al 2013). The factors that influence employee attitude includes employee empowerment (Stavrinoudis \& Simos, 2016), quality leadership (Asrar-ul-Haq \& Kuchinke, 2016), and work life balance (Iqbal, et al 2017). Customer loyalty is influenced by many factors, among which is attitude displayed by employees. Others are services pricing, quality, location and class of patrons (Thanabordeekij, 2018) can influence how the employee feel about their work and the prestige attached to it. All these influences the level of attitude of employees in the service sector including hotels and these actually work hand in hand (Namuleme, et al 2020).

\subsection{Customer Satisfaction}

Customer satisfaction is a measure of how products and services supplied by a business meet or surpass customer or client expectation (Fornell, et al 2020). Customer satisfaction is argued to be a psychological notion that involves the sensation of wellbeing and pleasure that is the outcome of obtaining what one hopes for and expects from a product or service (Kotler and Keller, 2016). It is a judgment that a product or service feature, or the product or service itself, provides pleasurable consumption related fulfilment (Basari \& Shamsudin, 2020).

Customer satisfaction is a dominant theme in the service sector (Kwizera, et al 2019) and more so in the hospitality industry. According to Leninkumar (2017) customer satisfaction is linked to customer loyalty, this suggests that pleased customers have the potential to become loyal customers and to attract new clients to the hotel. It is widely understood that customer satisfaction is crucial for enhancing profitability in the hospitality sector (Eklof, Podkorytova \& Malova, et al 2018). In a competitive marketplace where a business contends for customers, customer satisfaction is seen as a core differentiator and has progressively developed to become a main element of business strategy. Seeing that hotels of the same star category offer similar services it is comprehensible that they compete on the basis of better satisfy customers (Sánchez-Pérez, Illescas-Manzano \& Martínez-Puertas, 2020). This makes customer satisfaction an asset that should be scrutinised and managed just like any tangible asset. The relationship between customer service and customer satisfaction is a vital one (Kasemsap, 2017) and the role of employee attitude can never be underestimated.

Service quality is one of the factors that contribute to customer satisfaction and is therefore a component of customer satisfaction measure (Nunkoo, et al 2020). One of the main elements determining customer satisfaction is the customer's perception of service quality. Studies have shown that evidence support the relationship between customer satisfaction and service quality (Sharma \& Srivastava, 2018). Similarly studies also confirm the relationship between services environment and customer satisfaction (Namuleme, et al 2020). It is a fact that 
customer satisfaction is almost impossible and impractical without employee involvement (Bahadur, Aziz \& Zulfiqar, 2018).

\subsection{Employee Attitude and Customer Satisfaction}

It is argued that service is an attitude and outstanding service yields customers satisfaction (Kwizera, et al 2019). Outstanding service and profitable growth have a direct link, consequently, to employee attitude and satisfaction. In fact, the way employees feel about their employer has a significant effect on the overall business of a company. Employee attitude is not always easy to measure or control but neglecting it could have calamitous results for any company. According to Kurdi, Alshurideh and Alnaser (2020) there is a solid positive link between employee attitude and customer satisfaction. This suggests that if employees have bad attitude and low morale, their productivity and work quality would be radically lower than the required standards resulting in lower customer satisfaction, while the opposite would ring true if employees were happy and satisfied with a company. Lee, Moon and Song (2018) found similar relationship in their study, they also pointed out the fact that employees attitude reflected the quality of services. Kind and friendly employees tend to build rapport with customers which ultimately results in customer satisfaction (Lee et al 2018). Sebastiampillai and Holm (2017) found that job satisfaction, employee empowerment and customer orientation were significantly correlated with customer satisfaction. Customer service can be seen in the attitude of the staff towards the customer. It is said that service and for this matter, customer service is inseparable from the service provider (Bahadur, et al 2018). Numerous empirical studies show a strong positive relationship between employee satisfaction and customer satisfaction. As suggested by a wealth of findings (Nunkoo, et al 2020; Kloutsiniotis \& Mihail, 2018; Alhelalat, Ma'moun \& Twaissi, 2017; Singh et al 2017), positive changes in employee attitudes lead to positive changes in customer satisfaction. On the basis of the reviewed literature, the following null hypothesis is stated:

Ho1: Employee attitude does not significantly affect customer satisfaction in selected hotels in Kampala, Uganda.

\section{Methodology}

The study adopted a cross sectional survey design and a quantitative approach. A quantitative approach is strongly related to deductive testing of theories through hypotheses, while the cross sectional was design was adopted due to the fact that it makes data collection faster (Osunsan, 2020). The survey design was adopted because of its versatility in data collection; its effectiveness in collecting data on several variables at low cost and quickly; and its generalizability (Osunsan, 2020). Employees of 46 hotels in Kampala were considered for the study (Uganda Hotel Owners' Association, 2016), targeting 276 respondents and the response was 179. Simple random sampling was used to identify 6 hotel employees in the respective hotels. This sampling was adopted in the context of this study due to its ease, fairness, representativeness of the population, and the fact that it can be used to draw conclusions on the basis of the results of the study (Sharma 2017). The response rate was 65\%, which exceeded the $60 \%$ response rate considered to be minimally acceptable (Pickett, 2017). The research instrument consisted of 3 sections collecting data on demographic characteristics, employee attitude and customer satisfaction respectively. A four-point scale questionnaire was used to collect data on perception of employee attitude (11 items) and customer satisfaction (10 items); the four-point scale included: $1=$ strongly disagree; $2=$ disagree; $3=$ not sure and $4=$ agree. Some of Sebastiampillai and Holm (2017) suggestion were used as measures for customer satisfaction, while some of the indicators of Kwizera, et al (2019) were used for employee performance. The study found that the content validity index (CVI) of the instrument was 0.79 with reference to Masuwai and Saad (2017) who stated that if the CVI is $\geq 0.70$, the instrument can then be considered valid. The analysis was conducted using Means and Standard Deviations to compute the central tendency and measure of dispersion of the study variables. To interpret the mean values, the following numerical values and descriptions were used: 3.26-4.00 - Very good, 2.51-3.25 -Good, 1.76-2.50 -Moderate, and 1.00-1.75 -Poor. Additionally, inferential statistics was used to determine the variations in the dependent variable. Specifically, linear regression analysis was used to determine the effect of the independent variables on the dependent variable. In addition, simple regression analysis was conducted as: $\mathrm{Y}=\beta 0+\beta 1 \mathrm{X} 1+\mu$. Where, $\mathrm{Y}=$ independent variable, $\beta 0=$ intercept of $Y, \beta=$ parameter of the dependent variables, and $\mu=$ error term. The equation was converted in order to estimate the regression model as follows: $\mathrm{EA}=\beta 0+\beta 1 \mathrm{CS}+\mu$. Where $\mathrm{EA}=\mathrm{Employee}$ attitude, $\beta 0=$ Constant, $\beta 1=$ Coefficient of Customer Satisfaction, $\mu=$ Error term, CS $=$ Customer Satisfaction. The coefficient $\beta 1$ was used to identify the effect of employee attitude on customer satisfaction in selected hotels in Kampala, Uganda. A significant (positive or negative) coefficient would suggest a positive or negative effect of the employee attitude on customer satisfaction. All the tests were at the five percent (5\%) significance level which is the convention for the social sciences (Osunsan, 2020). 


\section{Findings}

\subsection{Characteristics of Respondent}

A big proportion (56.2\%) of the respondents were between 18 and 30 years of age. $56.2 \%$ of the respondents were females compared to only $43.8 \%$ who were males. More than half (53.1\%) were educated up to ordinary level, $28.1 \%$ were educated up to advanced level, only $15.6 \%$ were educated up to degree level, while only $3.1 \%$ had primary school education. The majority (93.8\%) of the respondents had worked for the hotel for less than 5 years and only $6.2 \%$ had worked for more than five years.

\subsection{Levels of Employee Attitude}

Table (1): Employee Attitude
\begin{tabular}{|l|c|c|c|}
\hline Item & Mean & Std Dev. & Interpretation \\
\hline Employee empowerment & 1.18 & 0.41 & Poor \\
\hline Approachable Management & 1.94 & 1.08 & Moderate \\
\hline Job requirements & 1.92 & 1.44 & Moderate \\
\hline Sufficient training & 1.16 & 0.37 & Poor \\
\hline Utilization of abilities/skills & 1.68 & 0.93 & Poor \\
\hline Perceived support: Coworkers & 1.59 & 0.98 & Poor \\
\hline Perceived support: Management & 1.24 & 0.62 & Moderate \\
\hline Work life balance & 2.02 & 1.89 & Poor \\
\hline Job satisfaction & 1.09 & 2.23 & Poor \\
\hline Organizational Commitment & 1.12 & 0.47 & Moderate \\
\hline Job Commitment & 1.95 & 1.04 & Poor \\
\hline Employee Attitude & 1.54 & 1.04 & \\
\hline
\end{tabular}

Table 1 shows that Job satisfaction ranked the poorest $($ mean $=1.09)$ while work life balance $($ mean $=2.02$; moderate) ranked highest. Table 1 further confirms that employee attitude is generally poor and this is accentuated by the fact that employee empowerment (mean=1.18), sufficient training (mean=1.16), perceived support (both), job satisfaction, and organisational commitment were all poor (mean $<1.76$ ). The moderate level in job commitment shows that employee like their chosen career this is confirmed by the moderate level in job requirement, but the poor level of organisation commitment shows that they do not have a strong bond to the organisation and will be willing to leave of the opportunity arises.

\subsection{Level of Customer Satisfaction}

Table (2): Perceived Customer Satisfaction

\begin{tabular}{|l|c|c|c|}
\hline Item & Mean & Std. Dev. & Interpretation \\
\hline Service delivery speed & 1.48 & 1.01 & Poor \\
\hline Employee courtesy & 3.05 & 1.55 & Good \\
\hline Service timing & 2.04 & 1.32 & Moderate \\
\hline Employee politeness & 2.12 & 1.58 & Moderate \\
\hline Employee accessibility & 2.08 & 1.57 & Moderate \\
\hline Employee timely response & 1.65 & 1.25 & Poor \\
\hline Employee get it right the first time & 1.57 & 1.73 & Poor \\
\hline Employee professionalism & 2.19 & 1.46 & Moderate \\
\hline Employee go above and beyond & 1.22 & 0.54 & Poor \\
\hline Employee ask for feedback & 1.14 & 0.43 & Poor \\
\hline Customer Satisfaction & 1.89 & 1.24 & Moderate \\
\hline
\end{tabular}

Table 2 reveals that perceived customer satisfaction is moderate (mean $=1.89$ ), however this is expected due to the fact that it is based on the perception of the employee and they would not want to rate themselves harshly. The generally moderate levels in several indicators show that customer satisfaction might not be at its best. Employee courtesy ranked highest with a mean of 3.05 (Good), followed by employee professionalism (mean = 2.19; moderate), while employee ask for feedback ranked lowest (mean =1.14; poor). The low mean scores can act as a good indicator of the true reflection of what customer service is probably like in the case study hotel.

\subsection{Employee Attitude and Customer Satisfaction}

Table (3): Effect of Employee Attitude on Customer Satisfaction

\begin{tabular}{|c|c|c|c|c|c|c|}
\hline \multicolumn{2}{|l|}{ Model } & \multicolumn{2}{|c|}{ Unstandardized Coefficients } & \multirow{2}{*}{$\begin{array}{c}\begin{array}{c}\text { Standardized } \\
\text { Coefficients }\end{array} \\
\text { Beta } \\
\end{array}$} & \multirow[t]{2}{*}{$t$} & sig \\
\hline & & & & & & \\
\hline & (Constant) & & 013 & & 1524 & 0000 \\
\hline & Employee Attitude & 0.42 & 0.040 & 0.767 & 10.49 & 0.000 \\
\hline $\mathrm{R}$ & 0.767 & & & & & \\
\hline $\mathrm{R}^{2}$ & 0.583 & & & & & \\
\hline Adjusted $\mathrm{R}^{2}$ & 0.558 & & & & & \\
\hline $\mathrm{F}$ & 109.949 & & & & & \\
\hline Durbin-Watson & 1.865 & & & & & \\
\hline Respondents & 179 & & & & & \\
\hline
\end{tabular}

Table 3 confirms that employee attitude has a significant positive effect on customer satisfaction by causing a variance of $55.8 \%(\mathrm{R} 2=0.558, \mathrm{P}<0.05)$. This implies that when employee attitude improves so does the level of customer satisfaction in the case study hotel. The study revealed that the regression model was the best fit for 
predicting the effect of employee attitude on customer satisfaction $(\mathrm{F}=109.95, \mathrm{P}>0.05)$. The Durbin-Watson $(\mathrm{d}=$ 1.87), which is between the two critical values of $1.5<\mathrm{d}<2.5$. Therefore, we can assume that there is no first order linear auto-correlation in our multiple linear regression data. On the basis of table 3 the null hypothesis (Ho1) is rejected and the alternate is accepted. Therefore, employee attitude does significantly affect customer satisfaction in selected hotels in Kampala, Uganda.

\section{Conclusions and Recommendations}

This study confirms the role of employee attitude in influencing customer satisfaction. More specifically it shows that employee attitude significantly effects customer satisfaction in the case study hotel. This finding resonates with others studies (Kurdi et al 2020; Lee et al 2018; Sebastiampillai \& Holm, 2017) from others part of the world. However, this study shows that employee attitude is poor in spite of the fact that several of the employees like their career, but not necessary their employment condition. This finding appears to be more specific to the context of the study and can suggest potential issues with customer satisfaction in the long run. Employee feelings about their job not only has an influence on their quality of work life, but also on tangible business outcomes such as customer satisfaction, sales, and ultimately profit (Kwizera et al 2019). Employees can significantly contribute to an organization's success by embracing a customer-centric approach in their work and work-related interactions all this however is contingent on the employees' attitude.

Given the influence of customer satisfaction on business profit in the long run, it is essential for hotels to understand what dimensions of service quality need to be monitored and used to develop customer satisfaction awareness, and customer-oriented work behaviours. This calls for employers to create a conducive work environment that can stimulate employee ability to develop, engage and be empowered in their jobs. When all is said and done employee attitude in the workplace is mostly influenced by the owners and top management in the organisation, due to the fact that they are the ones who can put in place what is needed to alter employee attitude. It cannot be over emphasized, that it is the responsibility of the owners and top management of the organisation, hotels in this case to ensure the happiness and welfare of its employees, which in turn would lead to positive employee attitude and thus customer satisfaction.

\section{References:}

[1] Alhelalat, J. A., Ma'moun, A. H., \& Twaissi, N. M. (2017). "The impact of personal and functional aspects of restaurant employee service behaviour on customer satisfaction". International Journal of Hospitality Management, 66: 46-53, https://doi.org/10.1016/j.ijhm.2017.07.001

[2] Asrar-ul-Haq, M., \& Kuchinke, K. P. (2016). “Impact of leadership styles on employees' attitude towards their leader and performance: Empirical evidence from Pakistani banks". Future Business Journal, 2(1): 54-64, https://doi.org/10.1016/j.fbj.2016.05.002

[3] Bahadur, W., Aziz, S., \& Zulfiqar, S. (2018). "Effect of employee empathy on customer satisfaction and loyalty during employee-customer interactions: The mediating role of customer affective commitment and perceived service quality". Cogent Business \& Management, 5(1): 1491780, https://doi.org/10.1080/23311975.2018.1491780

[4] Balta, S. (2018). "The influence of internal marketing on employee satisfaction in the service industry". Business Management Dynamics, 8(1): 12.

[5] Basari, M. A. M. D., \& Shamsudin, M. F. (2020). “Does Customer Satisfaction Matters?” Journal of Undergraduate Social Science and Technology, 2(1).

[6] Eklof, J., Podkorytova, O., \& Malova, A. (2018). "Linking customer satisfaction with financial performance: an empirical study of Scandinavian banks". Total Quality Management \& Business Excellence, 1-19.

[7] Fletcher, L., Alfes, K., \& Robinson, D. (2018). "The relationship between perceived training and development and employee retention: the mediating role of work attitudes". The International Journal of Human Resource Management, 29(18): 2701-2728, https://doi.org/10.1080/09585192.2016.1262888

[8] Fornell, C., Morgeson, F. V., Hult, G. T. M., \& VanAmburg, D. (2020). “Defining Customer Satisfaction: A Strategic Company Asset? In the Reign of the Customer (pp. 1-24)”. Palgrave Macmillan, Cham.

[9] Iqbal, I., Zia-ud-Din, M., Arif, A., Raza, M., \& Ishtiaq, Z. (2017). "Impact of employee engagement on work-life balance with the moderating role of employee cynicism". International Journal of Academic Research in Business and Social Sciences, 7(6), 1088-1101, https://doi.org/10.6007/ijarbss/v7-i6/3068

[10] Kasemsap, K. (2017). "The importance of customer satisfaction and customer loyalty in the service sector". In Handbook of research on strategic alliances and value co-creation in the service industry (pp. 59-82). IGI Global.

[11] King, C., So, K. K. F., \& Grace, D. (2013). “The influence of service brand orientation on hotel employees' attitude and behaviors in China". International Journal of Hospitality Management, 34: 172-180, https://doi.org/10.1016/j.ijhm.2013.03.004 
[12] Kloutsiniotis, P. V., \& Mihail, D. M. (2018). “The link between perceived high-performance work practices, employee attitudes and service quality". Employee Relations, 40 (5): 801-821, https://doi.org/10.1108/er-08-2017-0201

[13] Kotler, P., \& Keller, K. L. (2016). Marketing Management. India: Pearson

[14] Kurdi, B., Alshurideh, M \& Alnaser, A. (2020). "The impact of employee satisfaction on customer satisfaction: Theoretical and empirical underpinning". Management Science Letters, 10(15): 3561-3570, https://doi.org/10.5267/j.msl.2020.6.038

[15] Kwizera, M., Osunsan, O.K., Irau, F., Wandiba, A., Abiria, P., Bayo, I. (2019). "Effect of Organizational Change on Employee Performance among selected Commercial Banks in Bujumbura, Burundi". East African Scholars Journal of Economics, Business and Management, 2(4): 225-234.

[16] Lee, W. S., Moon, J., \& Song, M. (2018). "Attributes of the coffee shop business related to customer satisfaction". Journal of Foodservice Business Research, 21(6): 628-641, https://doi.org/10.1080/15378020.2018.1524227

[17] Leninkumar, V. (2017). "The relationship between customer satisfaction and customer trust on customer loyalty". International Journal of Academic Research in Business and Social Sciences, 7(4): 450-465, https://doi.org/10.6007/ijarbss/v7-i4/2821

[18] Maggon, M., \& Chaudhry, H. (2018). "Exploring relationships between customer satisfaction and customer attitude from customer relationship management viewpoint: An empirical study of leisure travellers". FIIB Business Review, 7(1): 5765, https://doi.org/10.1177/2319714518766118

[19] Mahmoud, M. A., Hinson, R. E., \& Anim, P. A. (2018). "Service innovation and customer satisfaction: the role of customer value creation". European Journal of Innovation Management, 21(3): 402-422, https://doi.org/10.1108/ejim-09-2017-0117

[20] Masuwai, A. M., \& Saad, N. S. (2017). "Evaluating the face and content validity of a Teaching and Learning Guiding Principles Instrument (TLGPI): A perspective study of Malaysian teacher educators". Geografia-Malaysian Journal of Society and Space, 12(3).

[21] Nakazibwe, S. M. (2018). “Comparative assessment of service quality in selected three- and four-star hotels in Kampala central business area."

[22] Nambooze, C. (2019). "Factors influencing staff retention and performance: a case study of selected hotels in Kampala city”. (Doctoral dissertation, Makerere University).

[23] Namuleme, B., Mugume, T., Osunsan, O.K., Nakato, S., Nakacwa, K.S. (2020). "Service Environment and Customer Satisfaction in Centenary Bank Kabalagala Branch, Kampala, Uganda". The International Journal of Business \& Management 8 (1): 16-22, https://doi.org/10.24940/theijbm/2020/v8/i1/bm2001-002

[24] Nunkoo, R., Teeroovengadum, V., Ringle, C. M., \& Sunnassee, V. (2020). "Service quality and customer satisfaction: The moderating effects of hotel star rating". International Journal of Hospitality Management, 91: 102414, https://doi.org/10.1016/j.ijhm.2019.102414

[25] Obiero, M. A. (2018). "Relationship Between Service Quality and Customer Satisfaction in Hotels in Nairobi County”. (Doctoral dissertation, United States International University-Africa).

[26] Ogbonnaya, C., Daniels, K., \& Nielsen, K. (2017). "Does contingent pay encourage positive employee attitudes and intensify work?". Human Resource Management Journal, 27(1): 94-112, https://doi.org/10.1111/1748-8583.12130

[27] Oni, A. A., Adewoye, O. J., \& Eweoya, I. O. (2016). “E-banking users' behaviour: e-service quality, attitude, and customer satisfaction". International Journal of Bank Marketing, 34 (3): 347-367, https://doi.org/10.1108/ijbm-12-2014-0175

[28] Osunsan, O.K. (2020). "Internationalising Growth: Performance and Internationalisation of Small-Scale Enterprises in Kampala, Uganda". Saarbrücken: LAP Lambert Academic Publishing.

[29] Pickett, J. T. (2017). "Methodological myths and the role of appeals in criminal justice journals: The case of response rates". ACJS Today, 41(3): 61-69.

[30] Sánchez-Pérez, M., Illescas-Manzano, M. D., \& Martínez-Puertas, S. (2020). "You're the only One, or Simply the Best. Hotels differentiation, competition, agglomeration, and pricing". International Journal of Hospitality Management, 85: 102362, https://doi.org/10.1016/j.ijhm.2019.102362

[31] Sebastiampillai, S., \& Holm, V. U. (2017). "The Effect of HR Practices on Employee and Customer Satisfaction-A Study of an Airport Infrastructure Manager". (Master's thesis, NTNU).

[32] Sharma, G. (2017). "Pros and cons of different sampling techniques". International journal of applied research, 3(7): 749752.

[33] Sharma, S., \& Srivastava, S. (2018). "Relationship between Service Quality and Customer Satisfaction in Hotel Industry". TRJ (Tourism Research Journal), 2(1): 42-49, https://doi.org/10.30647/trj.v2i1.20

[34] Shin, H., \& Kang, J. (2020). "Reducing perceived health risk to attract hotel customers in the COVID-19 pandemic era: Focused on technology innovation for social distancing and cleanliness". International Journal of Hospitality Management, 91: 102664, https://doi.org/10.1016/j.ijhm.2020.102664 
[35] Singh, H., Saufi, R. A., Tasnim, R., \& Hussin, M. (2017). "The relationship between employee job satisfaction, perceived customer satisfaction, service quality, and profitability in luxury hotels in Kuala Lumpur". Prabandhan: Indian Journal of Management, 10(1): 26-39, https://doi.org/10.17010/pijom/2017/v10i1/109101

[36] Stavrinoudis, T. A., \& Simos, D. (2016). “Factors affecting hotel employees' perception and attitude toward empowerment". Journal of Human Resources in Hospitality \& Tourism, 15(4): 416-439, https://doi.org/10.1080/15332845.2016.1148568

[37] Thanabordeekij, P. (2018). "Factors influencing customer loyalty in mobile network services in Myanmar". Panyapiwat Journal, 10(2): 47-59.

[38] Wikhamn, W. (2019). "Innovation, sustainable HRM and customer satisfaction". International Journal of Hospitality Management, 76: 102-110, https://doi.org/10.1016/j.ijhm.2018.04.009 